\title{
ANALISIS POLA PERJALANAN DAN AKTIVITAS WISATAWAN MILENIAL MANCANEGARA KE DESA PECATU, BADUNG
}

\author{
Aditya Maulana Pratama1, IP. Sudana ${ }^{2}$, NMS. Wijaya ${ }^{3}$ \\ ${ }^{1}$ Email: adityaamp31@gmail.com \\ Program Studi Industri Perjalanan Wisata, Fakultas Pariwisata, Universitas Udayana \\ 2Email: sudanaputu@yahoo.com \\ Program Studi Industri Perjalanan Wisata, Fakultas Pariwisata, Universitas Udayana \\ ${ }^{3}$ Email: sofia_ipw@unud.ac.id \\ Program Studi Industri Perjalanan Wisata, Fakultas Pariwisata, Universitas Udayana
}

\begin{abstract}
UNWTO predicts millenial tourists will become one of the biggest market shares for the tourism in the world and in Indonesia. Bali as a tourist destination and one of them is Pecatu Village, located in the area of South Kuta, Badung Regency as one of tourist destinations for millennial foreign tourists. According to this research millenials tourist are defined as the tourists group aged 16-37 years old. The purposes of this research are to find out characteristic, travel pattern and activities for the foreign millenial tourists visiting Pecatu Village. This research uses descriptive qualitative analysis, the sample was determined purposively by 100 respondent foreign millenial tourist. Data collection techniques were carried out by means of observation, questionnaires, interviews, literature studies and documentation. The results showed that Uluwatu Temple visited by $30 \%$ of total respondents with characteristics of millenial tourists are first timer tourist with the length of stay between 2 weeks -1 month, visiting with friends, organized their trip by themselves, using internet to get information and using motorbike as a transportation during their trip. There are 2 types of travel pattern namely single point and base trip while visiting tourist attractions and for the activites $68 \%$ them like to swimming, sunbathing, sightseeing and taking pictures.
\end{abstract}

\begin{abstract}
Abstrak: Prediksi UNWTO bahwa wisatawan milenial akan menjadi salah satu pangsa pasar terbesar bagi kepariwisataan dunia. Bali sebagai destinasi wisata dan salah satunya Desa Pecatu yang terletak di kawasan Kuta Selatan, Kabupaten Badung menjadi tujuan wisata bagi wisatawan milenial mancanegara. Berdasarkan penelitian ini wisatawan milenial adalah wisatawan yang berumur 16-37 tahun. Tujuan dari penelitian ini adalah untuk mengetahui karakteristik, pola perjalanan dan aktivitas wisatawan milenial mancanegara yang berkunjung ke Desa Pecatu. Penelitian ini menggunakan analisis data deskriptif kualitatif dan sampel ditentukan secara purposive sampling berjumlah 100 orang responden wisatawan milenial mancanegara. Teknik pengumpulan data dilakukan dengan cara observasi, kuesioner wawancara, studi kepustakaan dan dokumentasi. Hasil dari penelitian ini adalah Pura Uluwatu menjadi destinasi utama yang paling banyak dikunjungi dengan $30 \%$ dari total responden dan karakteristik wisatawan milenial mancanegara adalah wisatawan yang baru pertama kali berkunjung selama 2 minggu - 1 bulan, datang bersama teman, mengatur sendiri pengorganisasian perjalanan mereka, menggunakan internet sebagai sumber informasi dan sepeda motor merupakan moda transportasi yang dipilih untuk melakukan perjalanan wisata. Terdapat 2 pola perjalanan yang dilakukan oleh wisatawan milenial mancanegara ketika berkunjung ke daya tarik wisata yang ada di Desa pecatu, yaitu single point dan base trip, dan aktivitas wisatawan $68 \%$ adalah berenang, berjemur, melihat pemandangan dan mengambil gambar.
\end{abstract}

Keywords: activity foreign tourist, millenial tourist, pecatu village, travel pattern. 


\section{PENDAHULUAN}

Salah satu yang menjadi ujung tombak kepariwisataan di Indonesia adalah Provinsi Bali yang merupakan provinsi yang memiliki potensi pariwisata yang sangat besar. Bali merupakan daerah tujuan wisata yang terkenal di dunia, keindahan alam dan kebudayaan Bali yang unik dan beranekaragam menjadi daya tarik tersendiri bagi para wisatawan. Bali memiliki keunikan dan keunggulan kebudayaan, yaitu adanya perpaduan yang harmonis antara potensi kebudayaan yang masih memegang teguh adat istiadat dan sumber daya manusia dengan dukungan alam yang mempesona menjadi modal dasar dari keunggulan pariwisata daerah Bali. Dalam 5 tahun terakhir, jumlah wisatawan mancanegara yang mengunjungi Bali terus meningkat.

Konsentrasi pembangunan pariwisata di Bali lebih terletak di kawasan Bali Selatan, dikarenakan dengan banyaknya destinasi wisata yang berdekatan satu sama lain menjadi memudahkan untuk dikembangkan bagi pemerintah Bali. Salah satu Desa yang mempunyai beberapa daya tarik wisata yang menarik untuk diteliti adalah Desa Pecatu, dengan daya tarik utama adalah Pura Luhur Uluwatu yang sudah menjadi salah satu destinasi wisata utama di Bali, selain itu juga terdapat beberapa pantai dengan karakteristik pasir putih, ombak besar yang menantang, adanya beberapa kolam alami yang terbentuk dari batuan besar yang pecah terkena ombak yaitu Pantai Suluban, Pantai Dreamland, Pantai Padang-Padang, dan Pantai Bingin. Keberadaan pantai yang beradu dengan tebingtebing kokoh ternyata menjadi daya tarik luar biasa.

Dengan karakteristik daya tarik wisata yang telah dijelaskan diatas, hal tersebut sangatlah cocok dengan hal-hal yang disukai oleh wisatawan milenial. Kelompok wisatawan milenial adalah mereka yang ratarata berusia muda berkisar 18-34 tahun atau lebih dikenal dengan Generasi Y diperkirakan akan mendominasi pasar wisata dunia. Generasi ini dikenal sudah sangat melek dengan teknologi, bahkan hampir semua kegiatan yang dilakukan oleh generasi ini selalu berkaitan dengan teknologi. Hal tersebut didapat berdasarkan hasil penelitian yang dilakukan oleh Parhusip (2018) yang berjudul "wisatawan milenial ke Bali".

Salah satu karakteristik dari wisatawan milenial yaitu diversely motivated yang memiliki pengertian suka bepergian atau berpetualang dan dapat bepergian baik secara individu maupun berkelompok akan menghasilkan sebuah pola perjalanan dari wisatawan itu sendiri. Menurut Kamus Besar Bahasa Indonesia, kata pola mempunyai arti sebagai model, sedangkan perjalanan itu sendiri yang asalnya dari kata dasar yaitu jalan atau lintasan dan jika digabungkan mempunyai arti sebagai kegiatan perpindahan barang atau orang dari satu tempat ke tempat yang lainnya melalui sebuah jalur atau lintasan. Pola perjalanan wisatawan adalah sebuah keterkaitan mata rantai perjalanan dari tempat wisatawan tinggal selama di daerah tersebut (hub), melalui sebuah pintu masuk/keluar menuju sebuah destinasi (entry point) yang didalamnya terdapat fasilitas yang digunakan oleh wisatawan tersebut guna menunjang sebuah kegiatan kepariwisataan hingga atraksi wisata terkait dengan apa yang akan dilakukan, dilihat dan dibeli oleh wisatawan di sekitar daya tarik wisata tersebut.

Ketika wisatawan berkunjung ke sebuah daya tarik wisata, pastinya mereka akan melakukan sesuatu kegiatan yang biasa disebut juga sebagai aktivitas wisata, dengan banyaknya pilihan aktivitas wisata yang secara umum dibagi menjadi 3 yaitu aktivitas wisata alam, budaya dan khusus maka akan berdampak secara langsung dengan lama tinggal wisatawan khususnya wisatawan milenial mancanegara. Aktivitas yang paling banyak dilakukan oleh mereka di Desa Pecatu dapat berupa berselancar, bersantai di pantai dan melihat/mengunjungi pura, namun tidak menutup kemungkinan juga bahwa adanya aktivitas lain yang dilakukan oleh wisatawan milenial mancanegara seperti mengunjungi kafe dan restoran, menonton tarian/upacara adat juga berpotensi untuk menjadi aktivitas wisata favorit yang dilakukan oleh mereka.

Ketika wisatawan berkunjung ke sebuah daya tarik wisata, pastinya mereka akan melakukan sesuatu kegiatan yang biasa disebut juga sebagai aktivitas wisata, dengan banyaknya pilihan aktivitas wisata yang secara umum dibagi menjadi 3 yaitu aktivitas wisata alam, budaya dan khusus maka akan berdampak secara langsung dengan lama tinggal wisatawan khususnya wisatawan milenial mancanegara. Aktivitas yang paling banyak dilakukan oleh mereka di Desa Pecatu dapat berupa berselancar, bersantai di pantai dan melihat/mengunjungi pura, namun tidak 
menutup kemungkinan juga bahwa adanya aktivitas lain yang dilakukan oleh wisatawan milenial mancanegara seperti mengunjungi kafe dan restoran, menonton tarian/upacara adat juga berpotensi untuk menjadi aktivitas wisata favorit yang dilakukan oleh mereka.

Dengan besarnya pangsa pasar potensial di kalangan generasi milenial tersebut, peneliti tertarik untuk mengetahui pola perjalanan dan aktivitas dari wisatawan milenial mancanegara yang ada di Desa Pecatu agar nantinya dapat menjadi sebuah acuan dan standar yang dapat bermanfaat bagi pariwisata di Bali umumnya dan Desa Pecatu khususnya untuk lebih berhasil kedepannya dalam menggaet wisatawan milenial.

\section{METODE}

Studi ini dilakukan untuk mengetahui pola perjalanan dan aktivitas milenial mancanegara ketika berkunjung ke Desa Pecatu. Variabel yang digunakan adalah variabel pola perjalanan: single pattern, multiple pattern dan complex pattern sedangkan variabel aktivitas yang didalamnya: aktivitas wisata alam, budaya dan khusus.

Untuk mendapatkan data dalam studi ini digunakan beberapa teknik pengumpulan data antara lain: observasi, kuisioner, kepustakaan,dokumentasi.

Studi ini menggunakan kuesioner yang dibagikan kepada wisatawan millennial mancanegara yang sedang berkunjung ke daya tarik wisata yang ada di Desa Pecatu, Kabupaten Badung. Penentuan jumlah sampel menggunakan teori dari Hair, et al (2006). Yaitu jumlah dari indikator variabel observasi dikalikan 5 atau 10.

Dalam studi ini terdapat 11 pertanyaan yang diajukan kepada responden. Untuk mendapatkan jumlah responden maka jumlah pertanyaan dikalikan 5 atau 10. Dalam hal ini, peneliti memilih jumlah pertanyaan dikalikan 9 adalah 11x $9=99$ dibulatkan menjadi 100 . Jadi, total responden dalam studi ini sebanyak 100 orang. Kuesioner dibagikan secara purposive kepada 100 orang wisatawan millennial mancanegara yang sedang berkunjung ke Desa Pecatu.

Teknik analisis data yang digunakan pada studi ini adalah analisis deskriptif kualitatif. Metode ini dilakukan untuk mengungkapkan bagaimana pola perjalanan dan aktivitas dengan penyebaran kuesioner kepada wisatawan millennial yang yang sedang berkunjung ke Kuta Selatan.

\section{HASIL DAN PEMBAHASAN}

Lokus dalam penelitian ini bertempat di Desa Pecatu yang berjarak sekitar 16,5 km dari Bandara Internasional Ngurah Rai atau sekitar 40 menit jika berkendara dengan Motor atau Mobil. Lebih khususnya penelitian ini mengambil tempat di beberapa daya tarik wisata utama yang terletak di Desa Pecatu yaitu Pura Uluwatu, Pantai Dreamland, Pantai Bingin, Pantai Suluban dan Pantai PadangPadang. Kawasan ini juga biasa disebut surga bagi para peselancar dunia (surfer's paradise) dikarenakan memiliki salah satu dari beberapa ombak terbaik di dunia

\section{Karakteristik Wisatawan Millennial}

Karakteristik wisatawan millennial mancanegara yang berkunjung ke Desa Pecatu adalah sebagai berikut:

1. Lebih didominasi oleh wisatawan milenial mancanegara yang berjenis kelamin perempuan dengan presentase sebesar 58\%. Pada saat dilakukan penelitian banyak dari wisatawan perempuan yang datang secara sendirian.Hal ini dapat disimpulkan bahwa wisatawan perempuan sudah merasa nyaman dan aman dengan keadaan sekitar di destinasi-destinasi di Desa Pecatu.

2. Wisatawan yang berasal dari Eropa mendominasi lebih dari setengah kunjungan wisatawan milenial mancegara dengan wisatawan dari negara Jerman sebesar 25\% dari total seluruh responden, Hal ini memang menunjukkan bahwa wisatawan milenial Eropa sangat mendominasi dikarenakan destinasidestinasi di Desa Pecatu sangat cocok dengan karakteristik wisatawan Eropa yang menyukai aktivitas fisik seperti berenang dan berselancar serta dengan adanya Pura Luhur Uluwatu menambah keberagaman destinasi wisata budaya untuk dikunjungi oleh wisatawan.

3. Wisatawan milenial mancanegara dengan rentang waktu $20-24$ tahun mempunyai jumlah paling banyak yaitu $41 \%$ yang mana rentang usia tersebut telah memasuki usia produktif dan dewasa awal, wisatawan dengan usia ini sudah mampu menghasilkan uang sendiri serta memiliki waktu luang yang paling banyak 
dibandingkan dengan rentang usia lainnya, jika pendapatan mereka cukup untuk berlibur dan biaya untuk melakukan seluruh perjalanan relatif murah dengan perbedaan mata uang yang signifikan menjadikan salah satu faktor push dan pull bagi wisatawan.

4. Sebanyak 52\% wisatawan milenial mancanegar baik yang sedang menempuh maupun bergelar Sarjana S1 mempunyai presentase tertinggi dibanding dengan tingkat pendidikan yang lain. Hal ini dikarenakan dengan mempunyai gelar Sarjana S1, dari hasil wawancara singkat yang dilakukan kepada wisatawan adalah waktu yang tepat untuk melakukan perjalanan ketika mereka telah mempunyai cukup uang dan waktu luang sebelum mereka akan memasuki dunia kerja maupun melanjutkan pendidikan Magister S2.

5. Pekerjaan mayoritas wisatawan milenial mancanegara yang berkunjung ke Desa Pecatu didominasi oleh Pegawai Swasta sebesar $42 \%$ dan Mahasiswa sebesar $40 \%$. Pegawai Swasta banyak yang melakukan perjalanan dikarenakan mereka telah mandiri secara finansial sehingga bebas untuk mengalokasikan pendapatan sesuai dengan keinginan mereka sendiri dan mempunyai waktu luang dikala mengambil cuti ataupun jeda sewaktu akan beralih ke pekerjaan yang lainnya, sedangkan mahasiswa cukup banyak yang melakukan perjalanan dikarenakan mereka mempunyai waktu luang yang paling banyak dikala libur pergantian semester serta kebanyakan dari mereka sudah bekerja meskipun hanya sebagai pekerja paruh waktu (part-time).

6. Sebanyak $87 \%$ dari responden menjawab belum menikah, akan tetapi dari kebanyakan dari mereka datang bersama dengan pasangan mereka yang berarti mereka sudah mempunyai hubungan namun mungkin belum menikah secara resmi, sedangkan hanya $13 \%$ dari total responden yang menjawab sudah menikah.

7. Mayoritas wisatawan yang berkunjung ke Desa Pecatu adalah wisatawan yang baru pertama kali mengunjungi tempat tersebut (first timer) dengah hasil sejumlah $65 \%$. Wisatawan tersebut biasanya tertarik dengan pantai-pantai yang letaknya bisa dikatakan belum terlalu ramai dan letaknya yang cukup terpencil dibandingkan dengan kawasan pantai lain yang ada di Kuta maupun Seminyak. Sedangkan wisatawan dengan frekuensi kunjungan lebih dari sekali (repeater guest) baik yang pernah berkunjung sebanyak 2-3 maupun lebih dari 3 kali berjumlah $35 \%$. Mereka mayoritas sudah mengetahui lokasi destinasi wisata di Desa Pecatu sehingga memudahkan mereka untuk mencapai tempat tujuan.

8. Jumlah dari wisatawan milenial mancanegara yang berkunjung ke Desa Pecatu adalah wisatawan yang baru pertama kali mengunjungi tempat tersebut (first timer) dengah hasil sejumlah $65 \%$. Wisatawan tersebut biasanya tertarik dengan pantai-pantai yang letaknya bisa dikatakan belum terlalu ramai dan letaknya yang cukup terpencil dibandingkan dengan kawasan pantai lain yang ada di Kuta maupun Seminyak. Sedangkan wisatawan dengan frekuensi kunjungan lebih dari sekali (repeater guest) baik yang pernah berkunjung sebanyak 2-3 maupun lebih dari 3 kali berjumlah $35 \%$. Mereka mayoritas sudah mengetahui lokasi destinasi wisata di Desa Pecatu sehingga memudahkan mereka untuk mencapai tempat tujuan.

9. Setelah dilakukan penelitian terhadap 100 responden, dua kategori yang paling mendominasi adalah wisatawan yang melakukan perjalanan dengan teman maupun dengan pasangan, yaitu masingmasing sebesar 34\% dan 33\%. Hasil ini dapat disimpulkan bahwa wisatawan milenial yang masih berusia muda banyak yang melakukan perjalanan dengan seseorang saja, dalam artian ketika dilakukan penelitian mayoritas dari mereka menggunakan sepeda motor yang maksimal hanya memuat 1 pengemudi dan 1 penumpang saja.

10. Sebanyak $96 \%$ dari wisatawan milenial mancanegara mengatur perjalanan wisata mereka secara tersendiri, hal ini berarti sesuai dengan salah satu karakteristik wisatawan milenial dari Gunarsa (2012) yaitu Socioeconomically introverted yang mempunyai arti senang aktivitas mandiri dan tidak segan untuk membelanjakan uang pada produk/jasa sesuai kesenangan mereka. Pada umumnya para wisatawan milenial hanya membeli tiket pesawat 
yang biasanya mereka membeli secara online di situs internet daripada membeli sebuah paket wisata lengkap yang sudah termasuk paket komplit di dalamnya (all in). Dengan alasan mereka bisaa lebih bebas menentukan secara sendiri untuk destinasi wisata yang akan dituju tanpa dibatasi oleh waktu serta dapat berpindahpindah akomodasi sesuai selera wisatawan.

11. Presentase terbanyak sebanyak $72 \%$ wisatawan milenial mancanegara memilih internet sebagai sumber informasi yang digunakan sebelum mengunjungi destinasi wisata. Hal ini sesuai dengan karakteristik generasi milenial yaitu generasi yang menggunakan gawai sebagai salah satu bagian penting didalam hidupnya, ditunjang dengan sangat mendunianya konektivitas internet maka tidak mengherankan jika hampir 3/4 dari responden memilih internet sebagai sumber informasi.

12. Penggunaan transportasi oleh wisatawan milenial mancanegara terbagi menjadi 4 bagian (sepeda motor, mobil, bus, transportasi online) dengan hasil terbanyak adalah $76 \%$ wisatawan menggunakan sepeda motor sebagai moda transportasi, hal ini dipengaruhi oleh berbagai faktor, faktor paling banyak dikarenakan oleh kemudahan dalam menyewa sepeda motor,efisiensi waktu dan tidak adanya transportasi umum yang mumpuni untuk mencapai destinasi yang diinginkan oleh para wisatawan. Jumlah yang genap dari jumlah juga menunjukkan bahwa semua wisatawan milenial yang menggunakan sepeda motor berboncengan untuk menghemat biaya.

\section{Pola Perjalanan}

Daya tarik wisata di Desa Pecatu yang dikunjungi oleh wisatawan milenial mancanegara memiliki kebiasaan atau pola yang sama sesuai dengan minat dan karakteristik dari generasi milenial. Jika dihubungkan dengan konsep tipologi wisatawan, maka tipe wisatawan milenial mancanegara yang berkunjung adalah mayoritas didominasi oleh wisatawan dengan tipe allocentric dan explorer dikarenakan wisatawan milenial suka mengeksporasi serta berpetualang ke tempat yang baru meskipun mereka tidak mengetahui banyak tentang destinasi wisata yang akan dikunjungi dan hanya berdasarkan sumber informasi yang didapatnya dari internet, namun mereka tetap berani mengambil resiko guna memnuhi kebutuhan dan keinginan pribadinya.

Berdasarkan dari hasil penelitian yang telah dilakukan kepada 100 responden, didapatkan hasil bahwa $47 \%$ dari wisatawan menginap di kawasan Desa Pecatu yang terletak di kawasan Kuta Selatan yang memang mempunyai beberapa pilihan lengkap untuk akomodasi seperti Hotel, Hostel, Resort, Villa, dll. Maka dari itu hampir setengah dari responden menjawab bahwa mereka lebih memilih tinggal di tempat akomodasi yang memang dekat dengan lokasi destinasi wisata yang ingin mereka kunjungi, tempat terdekat kedua dengan lokasi penelitian adalah Desa Jimbaran letaknya bersebelahan langsung, $14 \%$ dari responden tinggal di daerah ini karena juga alasan lokasi yang cukup dekat dengan dengan Desa Pecatu. Terdapat wisatawan yang tinggal tidak di dua Desa tersebut melainkan di tempat lokasi lainnya yaitu Canggu, Kuta, Nusa Dua, Seminyak dan Ubud, namun jumlahnya tidak terlalu banyak dan umumnya mereka hanya sekedar ingin mengetahui salah satu dari 5 destinasi wisata yang ada di Desa Pecatu.

Ketika melakukan kegiatan perjalanan wisata, wisatawan tidak hanya bergerak dari tempat asal menuju ke suatu objek wisata tetapi juga bergerak mengunjungi objek wisata lainnya baik dua atau tiga objek wisata bahkan lebih sehingga seringkali perjalanan wisatawan tidak hanya mengunjungi satu objek wisata. Adanya perjalanan wisatawan yang seperti itu disebabkan oleh ketersediaan infrastruktur yang memadai. Pola perjalanan wisatawan sangat dipengaruhi oleh jalur dan lintasan yang dilalui oleh wisatawan. Jalur dan lintasan yang dilalui wisatawan dalam melakukan perjalanan wisata akan membentuk pola pergerakan sehingga terdapat pola langsung/direct route, pola lintasan jarak dekat/short traverse, pola lintasan jarak jauh/long traverse, dan pola kembali ke asal/loop. Pergerakan wisatawan terdiri dari beberapa tipe. Pergerakan wisatawan tersebut secara garis besar terdiri atas 3 tipe, yaitu single pattern, multiple pattern, complex pattern. Tipe pergerakan single pattern adalah single point sedangkan tipe multiple pattern dibagi lagi menjadi 3 tipe yaitu site, stopover, dan chaining loop. Tipe pergerakan complex pattern dibagi lagi 
menjadi 2 jenis yaitu destination region loop dan complex neighbourhood.

Terdapat dua tipe pola perjalanan wisatawan milenial mancanegara yang berkunjung ke Desa Pecatu, Salah satunya yaitu single point yang merupakan pergerakan wisatawan hanya mengunjungi salah satu destinasi di Desa Pecatu lalu setelah itu mereka akan kembali ke tempat tinggal atau akomodasinya melalui rute perjalanan yang terdekat. Dari 100 responden yang diteliti didapatlah hasil bahwa $26 \%$ dari responden hanya mengunjungi satu dari 5 destinasi wisata yang ada di Desa Pecatu, alasan dari para wisatawan milenial yang melakukan tipe perjalanan ini adalah karena mereka tidak tinggal di daerah Pecatu itu sendiri, terdapat beberapa tempat dimana mereka tinggal yaitu Canggu, Kuta, Jimbaran, Nusa Dua, Seminyak dan Ubud. 11 orang dari wisatawan hanya mengunjungi Uluwatu, 6 orang wisatawan mengunjungi Pantai PadangPadang, 5 orang dari wisatawan mengunjungi Pantai Suluban, 3 orang wisatawan mengunjungi Pantai Bingin dan 1 orang mengunjungi Pantai Dreamland.

Selanjutnya adalah wisatawan yang mengunjungi lebih dari satu destinasi, didalam penelitian yang penulis lakukan terdapat hasil bahwa $32 \%$ dari wisatawan mengunjungi 2 destinasi yang ada di Desa Pecatu, dilanjutkan dengan $25 \%$ wisatawan mengunjungi 3 destinasi wisata, didalam hal ini tipenya lebih mengarah kepada base site dimana wisatawan mengunjungi destinasi utama terlebih dahulu dan dilanjutkan menuju destinasi yang lainnya lalu kembali ke tempat dimana wisatawan tinggal. Dalam hal ini wisatawan milenial mancanegara lebih banyak yang memilih Pura Uluwatu sebagai destinasi utamanya lalu mengunjungi satu atau dua pantai yang letaknya berdekatan dengan lokasi Pura.Para wisatawan milenial biasanya memulai perjalanan di pagi hari dan langsung menuju ke Pura Uluwatu, Hal ini dikarenakan mereka ingin mengetahui kegiatan aktivitas wisata yang ada di Pura dan bisa disaksikan oleh wisatawan seperti pemandangan pura menghadap hamparan samudra hindia yang indah, arsitektur bangunan pura yang unik dan mengetahui lebih lanjut tentang budaya dan persembahyangan warga lokal Bali. Setelah mereka puas mengunjungi Pura, biasanya mereka akan menuju salah satu Pantai yang ada di Desa Pecatu di siang hari untuk melakukan berbagai aktivitas wisata dan bersantai, lalu biasanya wisatawan masih akan tinggal di salah satu pantai tersebut atau mengunjungi pantai lainnya untuk melihat matahari terbenam (sunset) dikarenakan semua pantai yang ada di Desa Pecatu dapat digunakan sebagai spot untuk melihat keindahan sunset, setelah itu mereka akan langsung kembali ke tempat dimana wisatawan tersebut tinggal.

\section{Aktivitas Wisatawan Milenial Mancanegara}

Aktivitas wisata adalah segala kegiatan yang dilakukan didalam maupun di luar atau di sekitar Daya Tarik Wisata. Aktivitas-aktivitas yang dilakukan tersebut dapat berupa aktivitas wisata alam, aktivitas wisata petualangan, aktivitas wisata khusus, aktivitas wisata budaya dan masih banyak lagi aktivitas lainnya. Terdapat 3 macam aktivitas wisata jika digambarkan secara umum yaitu aktivitas wisata alam, aktivitas budaya dan aktivitas wisata khusus. Didalam penelitian ini terdapat ketiga aktivitas wisata tersebut yang dapat dilakukan oleh wisatawan milenial mancanegara ketika berkunjung ke Desa Pecatu.

Aktivitas wisata alam adalah aktivitas yang dilakukan oleh wisatawan dengan memanfaatkan potensi sumber daya alam dan lingkungannya sebagai obyek tujuan wisata dimana biasanya daya tarik wisata tersebut menyuguhkan keindahan panorama alam yang indah dan kegiatan tersebut dapat menghilangkan stres, membuat wisatawan nyaman dan betah. Selanjutnya aktivitas wisata budaya adalah aktivitas yang dilakukan oleh wisatawan dengan tujuan keinginan untuk mengetahui kebiasaan-kebiasaan yang dilakukan oleh manusia di tempat lain yang tidak ada di tempat dimana para wisatawan berasal, kegiatan ini juga dapat melebarkan cara pandang hidup seseorang serta belajar mengenai kultur budaya yang baru. Terakhir, aktivitas wisata khusus merupakan kegiatan yang dilakukan oleh wisatawan untuk penyaluran hobby atau bakat dan juga untuk pemenuhan kebutuhan fisik jasmani dan rohani.

Setelah dilakukan pengidentifikasian, didapatlah hasil terhadap beberapa aktivitas wisatawan yang dapat dilakukan oleh wisatawan milenial mancanegara di Desa Pecatu yaitu adalah berenang, berselancar, berjemur, berbelanja, melihat pemandangan serta berfoto, menonton tarian atau upacara 
tradisional dan yang terakhir mengunjungi kafe, restoran dan beachclub. Data didapat dengan cara menyebarkan kuesioner kepada 100 wisatawan dan wisatawan diperbolehkan untuk mengisi lebih dari satu opsi pilihan jawaban aktivitas apa saja yang mereka lakukan selama berada dan mengunjungi Desa Pecatu.

Berdasarkan hasil penelitian diperoleh hasil bahwa wisatawan milenial mancanegara yang berkunjung ke Desa Pecatu mayoritas melakukan aktivitas kegiatan wisata di Pantai. Presentase hasil tertinggi yaitu adalah berenang dengan $68 \%$, hal ini tidak mengherankan dikarenakan 4 dari 5 daya tarik wisata utama di Desa Pecatu adalah pantai dan memang pantai-pantai di Desa Pecatu dikenal memiliki keindahan bawah laut yang cukup bagus, keadaan pantai yang masih bersih dan terjaga keasliannya menambah kenyamanan wisatawan untuk berenang di pantai. Aktivitas lainnya juga dapat dilakukan oleh wisatawan ketika berada di pantai, aktivitas berjemur dengan $58 \%$ juga mempunyai presentase yang cukup tinggi karena dengan kunjungan wisatawan mancanegara yang mayoritas berasal dari negara-negara di Eropa tentunya akan menikmati sengatan sinar matahari yang cukup terik di pinggir pantai. 35\% dari wisatawan memilih melakukan berselancar, dengan ombak yang cukup tinggi akan menantang adrenalin dari wisatawan untuk mencoba menaklukkan ombak-ombak di pantai-pantai yang ada di Desa Pecatu. Selain itu presentase tertinggi kedua dengan 63\% yaitu adalah melihat pemandangan dan berfoto ria di daya tarik wisata yang ada di Desa Pecatu. Dengan karakteristik wisatawan milenial yang secara gaya hidup tidak dapat terlepas dari gawai dan internet, aktivitas mengunjungi kafe, restoran dan beachclub di Desa Pecatu dilakukan oleh 53\% wisatawan milenial, fakta ini tidak mengejutkan karena tempat dimana wisatawan bisa mendapatkan sebuah hal yang didapatkan di kafe, restoran dan beachclub selain untuk menikmati makanan dan minuman adalah bisa mengambil gambar di tempat tersebut untuk kemudian mengunggahnya di media sosial karena ketika penulis lakukan observasi banyak sekali tempat yang mempunyai konsep yang cukup unik sehingga dapat menarik perhatian dari wisatawan milenial.

Dua aktivitas terendah yang kurang diminati oleh wisatawan milenial mancanegara ketika berkunjung ke Desa Pecatu adalah Menonton pertunjukan tarian atau upacara tradisional dan berbelanja masing-masing memiliki presentase sebesar $26 \%$ dan $16 \%$. Hasil ini memang sesuai dengan karakteristik wisatawan milenial yang kurang tertarik untuk mempelajari dan mengetahui sebuah budaya lain serta terhambat oleh faktor keuangan dimana generasi milenial pada umumnya masih merupakan pekerja yang baru beberapa tahun bekerja ataupun juga banyak pelajar yang menyisihkan sebagian dari uangnya untuk melakukan kegiatan traveling sehingga mereka akan lebih mempriotaskan menghabiskan uang untuk perjalanan dibandingkan dengan membeli sesuatu hal yang merupakan kebutuhan tersier.

Dengan beragamnya aktivitas yang dapat dilakukan oleh wisatawan akan menunjang juga lama waktu berkunjung wisatawan ke sebuah daya tarik wisata. Pantai Dreamland adalah tempat dimana wisatawan milenial mancanegara paling banyak menghabiskan waktunya selama kurang lebih 2 jam (115 menit). Wisatawan banyak menghabiskan waktunya disini karena banyaknya aktivitas wisatawan yang dapat dilakukan oleh mereka. Dengan adanya beragam aktivitas yang dilakukan oleh wisatawan mancanegara yang berlibur di sana memungkinkan wisatawan tersebut akan berkunjung lebih lama di daerah tujuan wisata tersebut. Dengan lama berkunjungan wisatawan semakin tinggi maka dengan sendirinya uang yang mereka belanjakan disana lebih banyak, sehingga ini juga membawa keuntungan bagi daerah tujuan wisata tersebut untuk meraup keuntungan yang lebih banyak dan dengan sendirinya akan meningkatkan kesejahteraan masyarakat setempat apabila segenap lapisan masyarakat dapat ikut ambil bagian dalam peluang tersebut sesuai dengan ketrampilan yang dimiliki. Selisih antara lama berkunjung wisatawan di empat pantai di Desa Pecatu tidak terlalu besar sehingga menunjukkan bahwa memang wisatawan lebih suka berlama-lama tinggal di pantai daripada di Kawasan Pura Uluwatu yang mempunyai ratarata kunjungan sebesar 58 menit. Hal ini dipengaruhi oleh aktivitas wisatawan yang terbatas ketika mengunjungi pura ini. 


\section{SIMPULAN DAN SARAN Simpulan}

Desa Pecatu saat ini menjadi salah satu destinasi wisaata tujuan utama bagi para wisatawan mancanegara, terdapat 5 daya tarik wisata utama yang berada di kawasan Desa ini, yaitu Pura Uluwatu, Pantai Bingin, Pantai Dreamland, Pantai Padang-Padang dan Pantai Suluban. Jika dilihat dari karakteristik sosiodemografisnya mayoritas wisatawan milenial mancanegara yang berkunjung ke Desa Pecatu berjenis kelamin perempuan, belum menikah, berasal dari negara Jerman, Australia, Inggris dan Spanyol, menempuh pendidikan hingga Sarjana dan berprofesi sebagai pegawai swasta. Ditinjau dari karakteristik perjalanannya mayoritas wisatawan merupakan wisatawan yang baru datang pertama kali ke Bali (first timer), berkunjung dalam kurun waktu 2 minggu - 1 bulan, datang dan melakukan perjalanan bersama teman, mengatur sendiri pengorganisasian perjalanan mereka, menggunakan fasilitas internet sebagai sumber informasi selama berada di Bali dan sepeda motor merupakan moda transportasi yang dipilih untuk melakukan perjalanan wisata.

Terdapat dua macam pola perjalanan paling umum dilakukan oleh wisatawan, yang pertama adalah pola single point yaitu wisatawan yang ketika melakukan perjalanan hanya mengunjungi satu destinasi wisata, dalam hal ini wisatawan hanya mengunjungi destinasi wisata yang dapat melakukan berbagai kegiatan wisata dan berkunjung dalam waktu yang paling lama. Selanjutnya adalah pola perjalanan base site, Pola perjalanan ini juga dibagi lagi menjadi dua bagian yaitu pola base site yang mengunjungi 2 daya tarik wisata dan pola base site yang mengunjungi 3 daya tarik wisata. Didalam pola base site yang mengunjungi 2 daya tarik wisata, mayoritas wisatawan mengunjungi Pantai yang terdekat dengan jalur masuk wisatawan (entry point) sebagai destinasi utama yang dikunjungi yaitu Pantai Dreamland, lalu wisatawan biasanya menngunjungi Pantai terdekat dari pantai tersebut yang mana adalah Pantai Bingin setelah itu mereka akan kembali ke tempat tinggal akomodasinya. Yang terakhir adalah pola perjalanan base site yang mengunjungi 3 daya tarik wisata yang ada di Desa Pecatu, didalam pola ini wisatawan biasanya memulai perjalanan dari tempat akomodasi dimana mereka tinggal menuju ke Pura Uluwatu sebagai tujuan utama, selanjutnya pada siang sampai dengan menjelang sore mereka biasanya akan melanjutkan perjalanan menuju ke pantai yang terdekat dengan lokasi pura yaitu Pantai Suluban, daya tarik wisata terakhir yang dikunjungi oleh wisatawan yaitu adalah Pantai Padang-Padang, para wisatawan biasanya berkunjung ke pantai ini dimulai dari sore hari hingga setelah matahari terbenam, setelah itu mereka akan kembali ke tempat akomodasinya.

Dalam beraktivitas ternyata wisatawan milenial lebih banyak melakukan aktivitas wisata alam seperti berselancar dan berenang daripada aktivitas wisata budaya dan khusus seperti menonton tarian, upacara adat, hal itu diperkuat dengan rata-rata lama berkunjung wisatawan ke daya tarik wisata pantai yang ada di Desa Pecatu jauh lebih lama daripada ke Pura Uluwatu.

\section{Saran}

Pemerintah diharapkan untuk lebih mampu lagi mempromosikan daya tarik wisata yang ada di Desa Pecatu dikarenakan jika dikembangkan lebih lanjut, maka akan lebih banyak lagi wisatawan mancanegara khususnya dari generasi milenial yang akan datang berkunjung karena sejauh ini meskipun sudah cukup baik ditinjau dari segi 4A (atraksi, aksesibilitas, amenitas, dan ansiliari) akan jauh lebih baik jika ditingkatkan lagi semua fasilitas sarana dan prasarana terutama dari segi aksesibilitas yang menuju ke beberapa destinasi masih kurang dan perlu perhatian lebih. 


\section{Kepustakaan}

Andrian, I Putu Dody. 2018. Pola Kunjungan Wisatawan Pada Daya Tarik Wisata di Kawasan Sarbagita. Denpasar : Universitas Udayana.

Ingkadijaya, Rahmat. 2016. Aktivitas Wisata Pilihan Keluarga Perkotaan. Vol.7. No.1. 2016. Jurnal Khasanah Ilmu.

Jabar, Abdul. 2017. Faktor-faktor yang Menentukan Minat Beli Wisatawan Surfing Mancanegara terhadap Pemilihan Akomodasi di Banjar Suluban Uluwatu Kuta Bali. Denpasar : Universitas Udayana.

Lau, Gigi \& McKercher, Bob. 2006. Understanding Tourist Movement Patterns In a Destination : A GIS Approach. China :The Hongkong Polytechnic University.

Lew, Alan \&Mckercher, Bob.2006. Modelling Tourist Movement: A Local Destination Analysis. China: The Hongkong Polytechnic University.

Maritha, D. P. 2009. Profil Pola Perjalanan Wisatawan Asing Ala Backpacker di Yoogyakarta.Surakarta: Universitas Sebelas Maret Surakarta.

Parhusip, Nina Ester. 2018. Wisatawan Milenial di Bali (Karakteristik, Motivasi dan Makna Berwisata). Vol.6. No.2. 2018. Jurnal Destinasi Pariwisata.

Sofi, Cholida\& Susilowati, M. H. Dewi. 2017. Faktor Pengaruh Pola Pergerakan Wisatawan di Kota dan Kabupaten Tegal.Jakarta : Universitas Indonesia.

Wirgantara, Agus \& Suryasih, Ida Ayu. 2014. Peranan Desa Adat Pecatu dalam Pelestarian Daya Tarik Wisata Pura Uluwatu di Kabupaten Badung. Vol.2. No. 2. 2014. Jurnal Destinasi Pariwisata. 